\title{
MANAJEMEN PEMBIAYAAN BANTUAN OPERASIONAL SEKOLAH DALAM MENINGKATKAN MUTU PENDIDIKAN PONDOK PESANTREN
}

\author{
Siti Mazidah \\ Universitas Islam Negeri Maulana Malik Ibrahim Malang \\ e-mail: zidaae2@gmail.com
}

\begin{abstract}
Financing is one of the keys to implementing an education. One source of funding sourced from the government is the School Operational Assistance (BOS) program. The purpose of this study was to: (1) describe the distribution of BOS funds in the education of Islamic boarding schools in the Ministry of Religion Office in Malang Regency, (2) explain the supervision of BOS funding in Islamic boarding school education, (3) describe the implications of BOS funding in improving quality Islamic boarding school education. This study uses a qualitative approach with a type of case study research. Data collection techniques used were observation, interviews, and documentation. Data is analyzed by reducing relevant data, describing and drawing conclusions. The results showed that, (1) the distribution of funding for BOS funds in the education of Islamic boarding schools in the Malang Ministry of Religion Office was carried out in accordance with the flow, (2) supervision of BOS funding in improving the quality of Islamic boarding school education was carried out according to the time of disbursement at the time of reporting of BOS funds, namely by direct and indirect supervision, (3) Implications of BOS funds in improving the education quality of Islamic boarding schools, namely: improving student achievement and learning outcomes and increasing teacher welfare.
\end{abstract}

Keywords. Financing Management, School Operational Assistance, Islamic Boarding Schools, Quality of Education

Abstrak. Pembiayaan merupakan salah satu kunci dalam terlaksananya suatu pendidikan. Salah satu sumber pembiayaan yang bersumber dari pemerintah adalah program dana Bantuan Operasional Sekolah (BOS). Tujuan penelitian ini adalah untuk: (1) mendeskripsikan penyaluran pembiayaan dana BOS pada pendidikan pondok pesantren di lingkungan Kantor Kementerian Agama Kabupaten Malang, (2) mendeskripsikan pengawasan pembiayaan dana BOS pada pendidikan pondok pesantren, (3) mendeskripsikan implikasi pembiayaan dana BOS dalam meningkatkan mutu pendidikan pondok pesantren. Untuk mencapai tujuan diatas, penelitian ini menggunakan pendekatan kualitatif dengan jenis penelitian studi kasus. Teknik pengumpulan data yang digunakan adalah observasi, wawancara, dan dokumentasi. Data dianalisis dengan cara mereduksi data yang relevan, memaparkan dan menarik kesimpulan. Hasil penelitian menunjukkan bahwa, (1) penyaluran pembiayaan dana BOS pada pendidikan pondok pesantren di lingkungan Kantor Kementerian Agama Kabupaten Malang telah dilakukan sesuai dengan alurnya, (2) Pengawasan pembiayaan dana BOS dalam meningkatkan mutu pendidikan pondok pesantren dilaksanakan sesuai dengan waktu pencairan atau penyaluran serta pada saat pelaporan dana BOS tersebut, yaitu dengan pengawasan secara langsung dan tidak langsung, (3) Implikasi dana BOS dalam meningkatkan mutu pendidikan pondok pesantren yaitu: meningkatkan prestasi dan hasil belajar santri serta meningkatnya kesejahteraan guru.

Kata Kunci: Manajemen Pembiayaan, BOS Pondok Pesantren, Mutu Pendidikan 
Copyright (C) JMPI: Jurnal Manajemen Pendidikan Islam. All Right Reserved. This is an open access article under the CC BY-NC-ND license (http://creativecommons.org/licenses/by-nc-nd/4.0/).

\section{A. PENDAHULUAN}

Pembiayaan pendidikan dalam konteks sistem pendidikan di Indonesia merupakan komponen strategik yang akan menentukan tercapai tidaknya tujuan-tujuan pendidikan yang telah ditetapkan. Dengan kata lain, bermutu tidaknya praktik pendidikan di Indonesia sangat dipengaruhi oleh komponen pembiayaan pendidikan. Pembiayaan pendidikan adalah sebagaimana yang diutarakan Nanang Fattah yang dikutip oleh Mulyono (2010) bahwa: pembiayaan pendidikan merupakan sejumlah uang yang dihasilkan dan dibelanjakan oleh lembaga untuk berbagai keperluan penyelenggaraan pendidikan seperti gaji guru, alat tulis kantor (ATK), kegiatan pengelolaan pendidikan, supervisi pendidikan, dan lain-lain. Berbicara tentang pembiayaan pendidikan, hal ini merupakan tanggung jawab yang besar bagi siapapun yang bersangkutan. Karena itulah penting bagi pemimpin untuk untuk memilih mereka yang berkompeten dalam bidang pembiayaan, selain kompeten juga harus memiliki sifat yang jujur, dengan begitu pembiayaan pendidikan di suatu sekolah/madrasah/pondok pesantren akan berjalan dengan efektif dan efisien. Sebagaimana sabda Rasulullah saw yang artinya: "Apabila suatu urusan diserahkan kepada yang bukan ahlinya, maka tunggulah masa kehancurannya" H.R. Bukhori, dalam Imam Muslimin (2013).

Melihat begitu strategiknya peran pembiayaan pendidikan, maka negara lewat UU Sisdiknas Nomor 20 tahun 2003, Pasal 46 menyatakan bahwa pendanaan pendidikan menjadi tanggung jawab bersama antara pemerintah, pemerintah daerah, dan masyarakat. Kemudian dalam BAB III Pasal 5 ayat (2) juga dinyatakan bahwa Pemerintah dan Pemerintah Daerah wajib menjamin tersedianya dana guna terselenggaranya pendidikan bagi setiap warga negara yang berusia tujuh sampai dengan lima belas tahun. Landasan yuridis ini diperkuat dengan PP. No. 48 tahun 2008, yang menyebutkan bahwa sumber pendanaan pendidikan bersumber dari anggaran Pemerintah Pusat, anggaran pemerintah daerah, dan dari masyarakat (Umi Zulfa, 2016).

Kebijakan pembangunan dalam kurun waktu 2004-2009 meliputi peningkatan akses bagi anak terhadap pendidikan yang lebih berkualitas melalui peningkatan pelaksanaan Wajib Belajar Pendidikan Dasar Sembilan Tahun dan pemberian akses yang lebih besar kepada kelompok masyarakat yang selama ini berkurang dapat menjangkau layanan pendidikan (Agustina, 2008). Pemerintah mengeluarkan Program Bantuan Operasional Sekolah (BOS) yang dimulai sejak Juli 2005. Program Bantuan Operasional Sekolah merupakan upaya pemerintah untuk melaksanakan amanat dari UndangUndang Dasar Negara RI tahun 1945 yang termuat dalam Pasal 31 ayat satu, dua, tiga dan empat.

BOS (Bantuan Operasional Sekolah) adalah program pemerintah untuk penyediaan pendanaan biaya nonpersonalia bagi satuan pendidikan dasar sebagai pelaksana program wajib belajar (Mulyono, 2010). Sebagaimana tertuang dalam PP Nomor 48 Tahun 2008 tentang Pendanaan Pendidikan, pendanaan pendidikan menjadi tanggung jawab bersama antara pemerintah, pemerintah daerah, dan masyarakat. Secara umum program BOS bertujuan untuk meringankan beban masyarakat terhadap pembiayaan pendidikan dalam rangka program wajib belajar 9 tahun yang bermutu. 
Program BOS memiliki sasaran semua sekolah tingkat SD dan SMP baik negeri maupun swasta yang ada di seluruh provinsi di Indonesia. Pada awalnya program kejar paket A, B, dan SMP terbuka tidak termasuk dari sasaran program BOS. Begitupun madrasah diniyah tidak berhak menerima dana BOS karena siswa telah terdaftar program BOS di sekolah reguler. Mulai tahun pelajaran 2007/2008 (mulai Juli 2007), SMP terbuka (regular dan mandiri) dan madrasah diniyah formal yang menyelenggarakan program wajib belajar sembilan tahun termasuk dalam sasaran program BOS. Besar dana BOS yang diterima oleh sekolah/madrasah/ponpes dihitung berdasarkan jumlah siswa dengan ketentuan yang berbeda setiap tingkatan (Agustina, 2008).

Melalui program BOS yang terkait pendidikan dasar 9 tahun, setiap pengelola program pendidikan harus memerhatikan hal-hal berikut : 1) BOS harus menjadi sarana penting untuk meningkatkan mutu Pendidikan Dasar 9 Tahun, 2) Dengan adanya BOS tidak boleh ada siswa miskin putus sekolah dikarenakan biaya, 3) Anak lulusan sekolah setingkat SD, harus melangsungkan pendidikan ke tingkat SMP, 4) Kepala sekolah mencari dan mengajak siswa yang akan lulus SD/setara dan berpotensi tidak melanjutkan sekolah untuk ditampung di SMP/setara. Dan juga mengajak anak yang putus sekolah dan masih berminat melanjutkan pendidikan, 5) Kepala sekolah harus mengelola dana BOS secara transparan dan akuntabel, 6) BOS tidak menghalangi peserta didik atau orangtua untuk memberikan sumbangan sukarela yang tidak mengikat kepada sekolah (Mulyono, 2010).

Pada awalnya, sasaran Program BOS Pondok Pesantren adalah Pondok Pesantren Salafiyah (PPS) penyelenggara Program Wajib Belajar Pendidikan Dasar dan dikelola secara terintegrasi dengan BOS madrasah. Namun sejak tahun 2015 disamping telah terjadi perluasan sasaran BOS yakni PPS, Mu'adalah dan Pendidikan Diniyah Formal, juga pengelolaan BOS Pesantren telah terpisah dari Madrasah sehingga berubah nama menjadi Bantuan Operasional Sekolah (BOS) Pada Pondok Pesantren.

Tujuan diberikannya dana Bantuan Operasional Sekolah kepada pondok pesantren adalah mencerdaskan kehidupan bangsa dan melahirkan sumber daya yang cerdas dan berkualitas. Akan tetapi menurut Hasan Aminuddin, ada beberapa kasus yang menunjukkan bahwa program dana Bantuan Operasional Sekolah tidak tepat sasaran dan tidak tepat guna (surabaya.tribunnews.com, 2017, April 12). Untuk itu pemerintah perlu penyaluran yang tepat dan pengawasan yang ketat agar tidak terjadi penyalahgunaan pada dana Bantuan Operasional Sekolah, karena pada dasarnya dana BOS (bantuan operasional sekolah) memiliki tujuan untuk meringankan beban masyarakat terhadap pembiayaan pendidikan, agar peserta didik yang tidak mampu dapat melaksanakan program wajib belajar 9 tahun yang bermutu.

Mutu memiliki konotasi yang beragam di benak banyak orang. Semuanya bergantung pada orang yang memakainya. Dalam bahasa Inggris, mutu adalah quality. Kata ini berasal dari bahasa latin yakni qualis yang secara leksikal bermakna what kind of (tergantung kata yang mengikutinya). Berikut beberapa konsep mutu yang diutarakan sejumlah pakar. Menurut Crosby, mutu adalah conformance to requirement (kesesuaian sesuatu dengan hal-hal yang disyaratkan). Suatu produk memiliki mutu, jika sesuai dengan standar, criteria mutu yang ditentukan. Standar mutu meliputi anasir bahan baku, proses produksi, dan produk jadi (Abdul Haris dan Nurhayati, 2010).

Dalam konteks pendidikan, pengertian mutu mencakup input, proses, dan atau output pendidikan (Depdiknas, 2001). Mutu bermanfaat bagi pendidikan karena dapat 
meningkatkan pertanggungjawaban (akuntabilitas) sekolah kepada masyarakat dan atau pemerintah yang telah memberikan semua biaya kepada sekolah, dapat menjamin mutu lulusannya, bisa bekerja lebih professional, serta meningkatkan persaingan yang sehat (Husaini, 2009). Berdasarkan pendapat di atas dapat disimpulkan bahwa mutu pendidikan merupakan kualitas atau ukuran baik atau buruk proses perubahan sikap dan prilaku seseorang atau kelompok dalam usaha mendewasakan manusia untuk mendekatkan diri kepada tuhan melalui bimbingan pengajaran dan pelatihan. Mutu pada pendidikan meliputi input, proses dan output. Input pendidikan dapat dinyatakan bermutu apabila siap berproses, dan proses pendidikan dapat dikatakan bermutu apabila mampu mencetak lulusan yang berkompeten.

Ada beberapa penelitian sebelumnya yang membahas tentang pengaruh manajemen pembiayaan dalam meningkatkan mutu pendidikan diantaranya Suwarni (2014) yang melakukan penelitian tentang Manajemen Pembiayaan Dalam Meningkatkan Mutu Pendidikan di Universitas Dehasen Bengkulu. Dalam penelitiannya ditemukan bahwa: Hasil yang dicapai dalam mutu pendidikan dalam Universitas Dehasen Bengkulu, walau dalam pelaksanaan pembiayaan belum berjalan secara maksimal, bukan berarti tidak memiliki hasil yang baik. Adapun hasil yang dicapai diantarnya, a) kompetensi lulusan sangat mendukung dalam dunia kerja, b) memiliki etos kerja yang baik, dan c) memiliki motivasi yang tinggi untuk melanjutkan pendidikan ke jenjang yang lebih tinggi.

Agustina (2008) dalam penelitiannya tentang Peranan Dana Bantuan Operasional Sekolah dalam Meningkatkan Mutu Pendidikan Agama Islam di MTs Negeri Mojokerto dan MTs Miftahul Ulum Ngoro Jombang menemukan bahwa: a) Hasil belajar siswa mengalami peningkatan setelah adanya BOS, b) meningkatnya prestasi akademik dan prestasi non akademik terkait dengan adanya program dana BOS buku.

Tujuan dari penelitian ini adalah untuk mendeskripsikan penyaluran dana bantuan operasional sekolah, pengawasan dana bantuan operasional sekolah, dan implikasi dana bantuan operasional sekolah dalam meningkatkan mutu pendidikan pondok pesantren di lingkungan Kantor Kementerian Agama Kabupaten Malang. Batasan dalam penelitian ini hanya pada permasalahan mengenai a) dana Bantuan Operasional Sekolah pada Pondok Pesantren, b) penyaluran, pengawasan, dan implikasi dari dana Bantuan Operasional Sekolah paada Pondok Pesantren.

\section{B. METODE PENELITIAN}

Adapun metode penelitian yang digunakan dalam penelitian ini adalah pendekatan kualitatif dengan jenis studi kasus. Menurut Deddy Mulyana (2005), studi kasus adalah uraian dan penjelasan komprehensif mengenai beberapa aspek seorang individu, suatu kelompok, suatu organisasi atau komunitas, suatu program, maupun situasi sosial. Dengan mempelajari semaksimal mungkin suatu kejadian, seorang individu maupun kelompok. Oleh karena itu peneliti mengamati secara langsung mengenai pembiayaan pendidikan dana Bantuan Operasional Sekolah pondok pesantren dari pihak Kementerian Agama dan juga pihak pondok pesantren. Penelitian ini dilaksanakan pada Kantor Kementerian Agama Kabupaten Malang pada bagian Pendidikan Diniyah dan Pondok Pesantren.

Teknik pengumpulan data pada penelitian ini melalui observasi, wawancara, dan dokumentasi. Selanjutnya, dari teknik pengumpulan data akan didapatkan sebuah data yang kemudian akan dianalisis dan ditarik kesimpulan. Hasil dari penelitian ini akan Vol. 3 No. 1, Juni 2018 JMPI homepage: http://ejournal.uin-malang.ac.id/index.php/jmpi/index 
diketahui cara penyaluran, pengawasan, serta implikasi dari dana BOS dalam meningkatkan mutu pendidikan pondok pesantren di lingkungan Kantor Kementerian Agama Kabupaten Malang.

\section{HASIL DAN PEMBAHASAN}

\section{Penyaluran Pembiayaan Dana Bantuan Operasional Pada Pondok Pesantren di Lingkungan Kantor Kementerian Agama Kabupaten Malang}

Setiap pemerintahan tentu memiliki bagian masing-masing dan setiap bagian memiliki jobdisc yang tertata untuk menjalankan program-program yang telah di buat, seperti halnya Kantor Kementerian Agama Kabupaten Malang yang memiliki banyak bagian, salah satunya yaitu seksi PD Pontren. Pada bagian PD Pontren setiap orang memiliki jobdesc masing-masing, yang mana salah satu dari staff tersebut memegang bagian terkait program BOS yang diberikan kepada pondok pesantren. Program bantuan tersebut berasal dari dana DIPA, dana tersebut harus dapat tersalurkan kepada masyarakat untuk meningkatkan kesejahteraan dan mutu bagi penerimanya. Dana DIPA tersebut disalurkan oleh PD Pontren melalui program Dana Bantuan Operasional Sekolah pada pondok pesantren salafiyah.

Penyaluran dana BOS pada pondok pesantren memiliki alur, baik dari pihak Kantor Kementerian Agama Kabupaten Malang maupun pihak pondok pesantren. Alur yang harus ditempuh untuk proses penyaluran dana BOS pada pondok Pesantren adalah:

a) Sosialisasi untuk memberitahukan kepada seluruh pondok pesantren penyelenggara program wajib belajar pendidikan dasar dicairkan.

b) Pengajuan bantuan harus serta dilampiri dengan Rencana Kegiatan dan Anggaran Pondok Pesantren guna mengetahui seberapa banyak dana yang akan dipergunakan oleh pihak penerima.

c) Pejabat pembuat komitmen menerbitkan surat keputusan terkait dengan penetapan pondok pesantren yang menerima dana bantuan tersebut,

d) Pejabat pembuat komitmen membuat perjanjian kerjasama dengan pimpinan pondok pesantren atau penanggung jawab program sebagai penerima Bantuan Operasional Sekolah, pembuatan perjanjian kerjasama dilakukan dengan maksud agar tidak terjadi suatu kerancuan pada dana tersebut.

e) Pejabat pembuat komitmen menyalurkan dana bantuan tersebut kepada pondok pesantren berdasarkan permohonan dan dilampirkan dengan Rencana Kegiatan dan Anggaran Pondok Peantren (RKAP), perjanjian kerjasama yang telah di tandatangani oleh kedua belah pihak dan kuitansi/bukti penerimaan yang sudah ditandatangani oleh penanggung jawab program wajib belajar pendidikan dasar.

Adapun dana Bantuan Operasional Sekolah untuk Pondok Pesantren yang dilaksanakan oleh Kantor Kementerian Agama Kabupaten Malang dalam penyalurannya menggunakan mekanisme pembayaran langsung (LS) melalui Kantor Pelayanan Perbendaharaan Negara (KPPN). Pencairan tersebut dilakukan pada 2 tahap. Tahap pertama 50\% dari keseluruhan dana, dibayarkan paling lambat minggu ke-empat pada bulan April sesuai dengan syarat yang ditetapkan, dalam pengajuan tersebut harus dilampiri dengan Rencana Kegiatan dan Anggaran Pondok Pesantren (RKAP).

Dalam realisasinya terdapat perbedaan jumlah nominal dana BOS yang diberikan pada tiap-tiap pondok pesantren karena menyesuaikan dengan (Rencana Kegiatan dan 
Anggaran Pondok Pesantren (RKAP) dan jumlah santri pada setiap pondok pesantren. RKAP ini berasal dari bagian manajemen yaitu Planning berasal dari kata plan yang artinya rencana, rancangan maksud, dan niat. Perencanaan merupakan kegiatan yang berkaitan dengan usaha merumuskan program yang didalamnya memuat segala sesuatu yang akan dilaksanakan, penentuan tujuan, prosedur dan juga metode yang akan diikuti dalam pencapaian tujuan (Saefullah, 2012).

Hasil penelitian ini menunjukkan bahwa penyaluran pembiayaan dana Bantuan Operasional Sekolah (BOS) kepada pondok pesantren di lingkungan Kantor Kementerian Agama Kabupaten Malang telah dilakukan sesuai dengan juknis yang ditetapkan. Hal ini sesuai dengan pendapat dari Mulyono (2010) bahwa pelaksanaan penyaluran dan pengelolaan dana Bantuan Operasional Sekolah wajib berpedoman pada Buku Panduan Pelaksanaan Bantuan Operasional Sekolah yang diterbitkan setiap tahun oleh Departemen Pendidikan Nasional dan Departemen Agama sebagai departemen teknis yang bertanggung jawab dalam pelaksanaan dan pengelolaan program tersebut.

\section{Pengawasan Pembiayaan Dana Bantuan Operasional Sekolah pada Pondok Pesantren di Lingkungan Kantor Kementerian Agama Kabupaten Malang}

Pengawasan pembiayaan dana Bantuan Operasional Sekolah dilakukan secara langsung dan tidak langsung. Pengawasan langsung adalah pengawasan yang dilakukan secara pribadi oleh pimpinan atau pengawas, dengan mengamati, meneliti, memeriksa, mengecek sendiri secara langsung ditempat pekerjaan dan menerima laporan-laporan secara langsung dari pengawasan. Pengawasan langsung dilakukan oleh pihak PD Pontren dengan mendatangi langsung pondok pesantren penerima dana Bantuan Operasional Sekolah untuk memeriksa dan mengecek bahwa penyaluran dan penggunaan dana Bantuan Operasional Sekolah tersebut sudah tepat. Sedangkan pengawsan tidak langsung dilakukan dengan mempelajari laporan-laporan yang diterima dari pelaksana baik lisan maupun tulisan, pengawasan tidak langsung ini dilakukan oleh pihak PD Pontren dengan memepelajari laporan dari pertanggung jawaban yang dibuat oleh pondok pesantren penerima Bantuan Operasional Sekolah.

Laporan merupakan pertanggung jawaban atas segala aktivitas maupun kegiatan yang telah dilakukan pihak penerima dana bantuan. Pemeriksaan anggaran atau pengawasan anggaran pada dasarnya merupakan aktivitas menilai baik catatan (record) dan menentukan prosedur dalam mengimplementasikan anggaran apakah sesuai dengan peraturan, kebijakan, dan standar-standar yang berlaku (Nanang Fattah, 2004). Oleh karena itu laporan pertanggung jawaban dari penerima dana Bantuan Operasional Sekolah dapat dilihat, dan diperiksa kembali kesesuaiannya dengan standar yang ada dan juga keterkaitannya dengan petunjuk teknis, dengan begitu akan mudah untuk memonitoring antara rencana anggaran dan juga realisasi yang dilakukan oleh pondok pesantren.

\section{Implikasi Pembiayaan Dana Bantuan Operasional Sekolah dalam Meningkatkan Mutu Pendidikan Pondok Pesantren}

Dana Bantuan Operasional Sekolah dapat meningkatkan hasil belajar santri, yang dilihat dengan prestasi yang diraih siswa, seperti yfang dinyatakan oleh Crosby: mutu adalah kesesuaian sesuatu dengan hal-hal yang disyaratkan. Suatu produk dapat dikatakan bermutu jika sesuai dengan standar kriteria mutu yang ditentukan. Standar mutu tersebut meliputi anasir bahan baku, proses produksi, dan produk jadi. 
Dalam peningkatan mutu pendidikan di pondok pesantren dapat dilihat dari fasilitas yang diberikan kepada santri dan juga proses dalam setiap pembelajarannya, dengan fasilitas yang dirasa memadai bagi para santri, maka akan menghasilkan output atau produk yang sesuai dengan diharapkan. Seperti halnya dengan pondok pesantren Raudlatul Ulum 1 Putra dengan fasilitas pembelajaran yang dimiliknya mampu membangun semangat santri dalam belajar sehingga mampu mencetak prestasi yang luar biasa. Dapat dikatakan perpustakaan merupakan fasilitas yang memiliki pengaruh cukup besar karena dengan adanya perpustakaan akan dapat menambah pengetahuan. Dengan begitu santri akan dapat bersaing dan mencetak prestasi di dunia luar dengan ilmu yang mereka miliki. Para santri mampu bersaing dengan kemampuan yang mereka miliki, terbukti dengan menjuarai lomba pada tingkat nasional pada ilmu nahwu dan fiqih.

Dana BOS dapat dibelanjakan oleh lembaga untuk berbagai keperluan penyelenggaraan pendidikan seperti gaji guru, peningkatan profesional guru, alat tulis kantor (ATK), kegiatan ekstrakurikuler, kegiatan pengelolaan pendidikan, juga supervisi pendidikan (Mulyono, 2010). Oleh karena itu di setiap pondok menggunakan dana tersebut untuk untuk meningkatkan semangat bagi para guru dalam mendidik para santri. Hal tersebut termasuk biaya personalia yang terdiri dari gaji pendidik dan tenaga kependidikan serta tunjangan yang melekat pada gaji (Mulyono, 2010). Dengan adanya honor atau tunjangan yang diberikan kepada guru/ustadz maka akan memiliki tanggung jawab dan semangat dalam menjalankan tugas yang diemban, karena guru/ustadz bertugas untuk mendidik para santri.

\section{E. KESIMPULAN}

Setelah melakukan penelitian dan analisis dari hasil penelitian, maka ada tiga kesimpulan yang sesuai dengan fokus penelitian, yaitu:

1. Penyaluran pembiayaan dana Bantuan Operasional Sekolah pada Pondok Pesantren telah dilaksanakan seperti petunjuk teknis yang telah dibuat, yang mana dalam penyaluran harus melalui tahapan-tahapan seperti pembuatan Rencana Kegiatan Anggaran Pondok Pesantren

2. Pengawasan pembiayaan dana Bantuan Operasional Sekolah dilakukan dengan cara langsung dan tidak langsung.

3. Implikasi dari pembiayaan dana Bantuan Operasional Sekolah dapat dilihat dari meningkatnya hasil belajar santri yang dilihat dari prestasi yang telah diraih, prestasi diraih karena fasilitas pembelajaran yang cukup untuk mendorong semangat belajar santri, dengan dana Bantuan Operasional Sekolah pada pondok pesantren juga dapat menambah semangat ustadz/guru.

Berdasarkan kesimpulan yang telah diuraikan, perlu kiranya peneliti memberikan sumbangan pemikiran yang berupa saran-saran bagi semua pihak:

1. Kepada pihak PD Pontren Kantor Kementerian Agama Kabupaten Malang di harapkan untuk terus memantau penyaluran dan terus memberi pengawasan terhadap dana Bantuan Operasional Sekolah di tingkat pondok pesantren, agar dana Bantuan tersebut benar-benar tersalurkan kepada yang berhak menerima dan dapat meningkatkan mutu pendidikan, baik mutu santri, guru, dan sarana prasarana.

2. Kepada pihak pondok pesantren diharapkan dana Bantuan Operasional Sekolah di gunakan dan di manfaatkan dengan baik agar mutu pendidikan pondok pesantren 
semakin meningkat, dan tidak menggunakan dana tersebut untuk hal-hal lain yang tidak berkaitan dengan peningkatan mutu pendidikan pondok pesantren.

3. Bagi peneliti lanjutan, diharapkan hasil penelitian ini dapat dijadikan sumber referensi, serta diharapkan untuk dilakukan penelitian lebih lanjut serta mendalam mengenai pengelolaan dana Bantuan Operasional Sekolah pada pondok pesantren yang dirasa masih perlu perbaikan dan penelitian yang berkelanjutan dengan menggunakan fokus yang lain, sebab dalam penelitian ini masih banyak kekurangan dan keterbatasan.

\section{DAFTAR PUSTAKA}

Abdul Haris dan Nurhayati. (2010). Manajemen Mutu Pendidikan. Bandung: Alfabetha Agustina, Dwi Farida. (2008). peranan dana BOS (Bantuan Operasional Sekolah) dalam meningkatkan mutu pendidikan agama islam di MTs Negeri Mojokerto dan MTs Miftahul Ulum Ngoro Jombang, Skripsi, Fakultas Tarbiyah UIN Maliki Malang.

Depdiknas. (2011). Manajemen Peningkatan Mutu Berbasis Sekolah. Jakarta: Depdiknas.

Fattah Nanang. (2004). Ekonomi dan Pembiayaan Pendidikan. Bandung: PT Remaja Rosdakarya.

Husaini, Usman. (2006). Manajemen: Teori, Praktek dan Riset Pendidikan. Jakarta: Bumi Aksara.

Aliran Dana BOS Dinilai Tak Efektif. (2017, April 12). Surya. Diambil dari http://surabaya.tribunnews.com/2017/04/12/aliran-dana-bos-dinilai-tak-efektif

Muslimin, Imam. (2013). Pemimpin Perubahan Model Kepemimpinan dalam Transisi Perubahan Kelembagaan. Malang: UIN Maliki Press.

Mulyana, Deddy. (2005). Metodologi Penelitian Kualitatif: Paradigma Baru Ilmu Komunikasi dan Ilmu Sosial Lainnya. Bandung: Remaja Rosdakrya.

Mulyono. (2010). Konsep Pembiayaan Pendidikan. Jogjakarta: Ar-Ruzz Media.

Saefullah. (2012). Manajemen Pendidikan Islam. Bandung: CV Pustaka Ceria.

Suwarni. (2015). Manajemen Pembiayaan Dalam Meningkatkan Mutu Pendidikan Di Universitas Dehasen Bengkulu. Jurnal Ekombis Review, Vol 3 No 1. Diambil dari https://jurnal.unived.ac.id/index.php/er/article/view/97 